\title{
German-United States Competition in World Markets
}

\author{
By G. B. Roorbach?
}

Harvard University, School of Business Administratron, Cambridge, Mass.

F EAR has been expressed repeatedly since the armistice that United States manufacturers could not tneet German competition in selling manufactured goods in world markets; not only that, but that the United States itself would be flooded with German wares to the detriment of American production. The fact that such a "flood" of imports into the United States has not materialized and that the export trade of the United States during the past three years has more than held its own in comparison with other nations, has apparently not removed the belief that German competition in manufactures is a black cloud overshadowing our commercial revival. That there is no competition with Germany to be met and respected, no one acquainted with the facts will deny; but that the force of this competition has been greatly overemphasized and that much of the fear is groundless, is also clear.

Much of the fear in regard to meeting German competition has been based on the following arguments:

(1) There had been an accumulation of goods in Germany during the war, ready for dumping in foreign markets.

(2) German industrial recovery, it was stated, was bound to be rapid, and German factories would turn out goods at a rapid rate and at less cost than most of her rivals.

(3) Germany's ability to undersell in foreign markets would be greatly facilitated by the depreciated exchange value of the mark, currency inflation within Germany, and the generally abnormal conditions of trade and exchange.

Let us examine the force of these reasons in the light of the experience of the past two years and the present situation existing in Germany.

(1) That Germany did not have large accumulations of exportable goods waiting to be dumped into foreign markets on the first: favorable opportunity has been demonstrated by the events of the past three years. German export figures give no indication that there were large stocks waiting shipment. The nearest approach to this condition was possibly in the case of toys. It is probable, also, that the embargoes against German dyes and chemicals in Italy, the United Kingdom, and the United States prevented much larger exports of these articles, but, taking trade as a whole, Germany has been found to have a deficiency, not a surplus, of exportable goods. German agents booked many orders in foreign countries, but German factories have been unable to fill them. If we compare the export trade of Germany for 1921 with pre-war years, we find that where German exports in 1912 were valued at $8,956,000,000$ gold marks, and in 1913 at $10,096,500,000$ gold marks, for the last eight months of 1921 they were valued at 4,591,000,000 gold marks (statistics for the whole year not available). In volume the corresponding figures were:

$\begin{array}{ll}1912 & 67,331,900 \text { tons } \\ 1913 & 75,432,000 \text { tons } \\ 1921-8 \text { months } & 13,721,160 \text { tons }\end{array}$

During the first half of 1922 there was a tendency to an increase in exports, but the June and July exports in tons have again declined to the 1921 average. Monthly trade statistics are given in the following table:

1 Received August 9, 1922.

2 Professor of Foreign Trade, Harvard University, School of Business Administration.

\begin{tabular}{|c|c|c|c|c|}
\hline \multirow{2}{*}{$\begin{array}{c}Y_{\text {EAR AND }} \\
\text { MONTH } \\
\text { Monthly } \\
\text { Average: }\end{array}$} & \multicolumn{4}{|c|}{ MERCHANDISE } \\
\hline & $\begin{array}{l}\text { In Millions } \\
\text { of Marks }\end{array}$ & $\begin{array}{l}\text { In Thotsands } \\
\text { of Metric Tons }\end{array}$ & $\begin{array}{l}\text { In Millions } \\
\text { of Marks }\end{array}$ & $\begin{array}{l}\text { In Thousands } \\
\text { of Metric Tons }\end{array}$ \\
\hline $\begin{array}{r}1913 \\
1920 \\
1921\end{array}$ & $\begin{array}{r}890 \\
9.9 \dot{1} \dot{0}\end{array}$ & $\begin{array}{l}\mathbf{6}, 073 \\
1,570 \\
2,194 \\
\end{array}$ & $\begin{array}{r}841 \\
5,776 \\
8,295\end{array}$ & $\begin{array}{l}6,141 \\
1,651 \\
1,715\end{array}$ \\
\hline $\begin{array}{l}\text { July } \\
\text { August } \\
\text { September } \\
\text { October } \\
\text { November } \\
\text { December } \\
\text { 1922: }\end{array}$ & $\begin{array}{r}7,572 \\
9,382 \\
10,642 \\
13,814 \\
12,273 \\
13,702\end{array}$ & $\begin{array}{l}1,925 \\
2,111 \\
2,533 \\
3,005 \\
2,535 \\
2,086\end{array}$ & $\begin{array}{r}6,175 \\
6,670 \\
7,492 \\
9,681 \\
11,886 \\
14,468\end{array}$ & $\begin{array}{l}1,558 \\
1,828 \\
1,871 \\
1,973 \\
1,908 \\
1,930\end{array}$ \\
\hline $\begin{array}{l}\text { January } \\
\text { February } \\
\text { March } \\
\text { April } \\
\text { May } \\
\text { June. } \\
\text { July }\end{array}$ & $\begin{array}{l}12,641 \\
12,001 \\
22,919 \\
28,266 \\
32,417 \\
34,364 \\
45,738\end{array}$ & $\begin{array}{l}2,309 \\
1,475 \\
2,645 \\
2,889 \\
3,810 \\
4,030 \\
4,798\end{array}$ & $\begin{array}{l}14,394 \\
14,482 \\
21,285 \\
22,948 \\
27,080 \\
30,232 \\
35,707\end{array}$ & $\begin{array}{l}2,027 \\
1,747 \\
2,153 \\
2,760 \\
2,093 \\
1,880 \\
1,636\end{array}$ \\
\hline
\end{tabular}

The following table gives a comparison for certain commodities, mostly manufactured, for 1912 and the second half of 1921 . Exports were probably greater the second half of the year than during the first half.

Princtal articlas Exportep from Germany in 1912 and ine Las' SiX MONTHS OF 1921

ARTICLES

Aniline and other coal-tar dyes.

Automobiles, passenger.

Chinaware, ineluding insulator.

Coal, bituminous.

Copper and alloys, and manufactur.

Cotton fabrics.......... other ................ lectrical apparatus:

Dynamos, motors, and transformers

Electrical appliances for illumination, trans mission of power, and electrolysis....

Glass, hollow

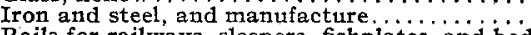

Rails for railways, sleepers, fishplates, and bed-

\section{plates.}

eather, upper, for boots, shoes, and slippers. Machinery of all kinds, except electrical .....

Paper and cardboard and manufactures..........

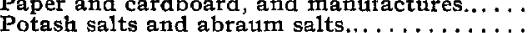

Potash salts and abraum salts.

Toys and Christmas-tree decorations.........

1 Trade Information Bulletin

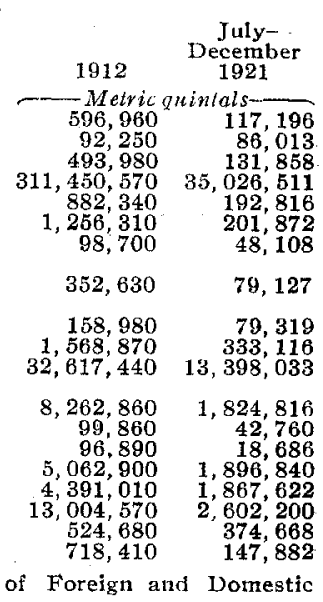
Commerce.

It is true that when trade with Germany was resumed there were times when quantities of German goods were suddenly dumped in certain markets, and temporary consternation resulted in the industries affected. But those sales were like bankruptcy auction sales, temporarily disturbing to the local market and causing embarrassment to local merchants. Unemployment in industrial countries to-day cannot, except possibly in rare instances, be traced to German competition. In a country like England, for example, unemployment, as far as it is affected by Germany, is due to the lack of commercial prosperity in Germany, rather than the reverse. Fnglish mills might be more fully employed if the German market for English goods could be brought back to its pre-war status, but Germany is a poor purchaser under the present abnormal economic and financial conditions that there exist.

(2) The ability of German factories to manufacture on a large scale for export, and at prices so low that they could not be met by foreign competitors, has been greatly overestimated. Much of Germany's post-war industrial activity was in answer to her domestic needs. As in other countries, the war left German industrial and transportation equipment greatly ruln down. 
Much of the country's production has been needed for replacement, repair, and equipment, and consequently a smaller proportion of industrial production has been available for export.

The restriction of exports has been aided also by the tax system, causing manufacturers to invest heavily in equipment in order to avoid excess profit and other taxes. New taxes and the proposed enforced loans are bound to fall with increasing severity on German industry, giving an increasing burden that must inevitably add to manufacturing costs.

Furthermore, the constantly depreciating currency in Germany has encouraged domestic buying on an unprecedented scale. With the internal value of the mark declining, the German people have transferred their accumulated marks at once into tangible objects. There has been an enormous speculative buying at home, giving temporary support to industrial development that must stop whenever the mark ceases to decline in value.

Pre-war relations between production and exports, says Commercial Attache Herring of Berlin in his reports to the Department of Commerce, are not being maintained. German industry as a whole is producing perhaps 60 per cent of its prewar output, but a much less percentage of that production is entering export trade as compared to pre-war years.

Industrial production in Germany is handicapped by increasing difficulties in obtaining raw materials and fuel. Her colonies are gone and her home territory has been deprived of rich rawmaterial-producing sections. The curtailment of coal-producing areas, the necessity of delivering coal as part of reparations payments, strikes, and general unrest are resulting in coal shortages that are seriously interfering with iron and steel production and industry in general. Pig iron shortage is repeatedly reported. Importation of coal from Great Britain, at high prices, has been increasing in recent months and now exceeds pre-war imports. The most important raw materials importedand Germany is dependent on many such-are very high in price because of exchange and credit conditions, and in some cases not obtainable at any price.

Nearly all other costs of production are rapidly increasing. Freight rates have been again and again advanced, and in June were reported 60 to 70 times higher than pre-war. Wage increases are constant, wage agreements not being made for a period longer than one month. In spite of wage increases, prices have so much more rapidly increased in Germany, that the German workman is actually underpaid and his efficiency is much less than formerly. The productivity of German labor, according to Commercial Attaché Herring, is less by 20 to 25 per cent than before the war, on account of the lowering of the standard of living. This is without reference to the eight-hour day now prevailing. It is evident that whatever advantages Germany had for cheap production for export immediately after the war were temporary. With each sticceeding month these advantages have become fewer and less effective.

(3) Much emphasis has been laid upon the advantages accruing to Germany in selling abroad because of the depreciated exchange value of the mark. As long as the external value of the mark was rapidly falling and the internal value only slowly declining, whatever products Germany had available for export, it is true, had a decided advantage over countries with stable currencies. But at best such a condition can be only temporary, although while it lasts opportunity for dumping is large: It is an indication of economic weakness, however, and points its own destruction.

To save herself from exchange losses Germany early attempted to equalize export prices and world prices by adding an export tax sufficient to make the actual exchange price somewhere neat the world price level. Trade that depends on a continuous depreciation of the exchange value of currency is on an exceedingly insecure foundation.
Currency inflation, such as has taken place in Germany; in connection with a greatly depreciated foreign exchange at first gave German products large price advantages in foreign matkets. Domestic prices, transportation costs, and wages have, however; rapidly adjusted themselves in Germany until at present the disparity between German wages and prices and world wages and prices is slight. Further currency depreciation can be less effective in the future in producing a wide spread between world prices and German domestic prices. When further depreciation stops, inflation can of course be of no benefit to trade. In fact, to stabilize the value of the mark, not to mention improvement in its value, will be likely to result in widespread industrial depression in Germany. In the long run, currency inflation and depreciating exchange weakens a country's ability to compete in world markets. It is, of course, itself a sign of economic and commercial deterioration.

An indication of the rise in prices in Germany is given in the Frankfurter Zeitung Wholesale Price Index. As shown in the table. below, prices on July 1, 1922, were more than double prices on the preceding January; and January 1922 prices were over 42 times those of 1914 .

WhOLESALE PRICE INDFX: Germany

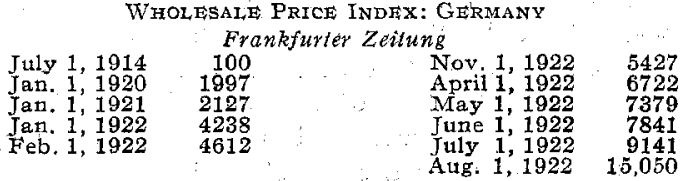

As a result of the instability of prices and wages caused by fluctuating exchanges and currency depreciation, trade, both foreign and domestic, becomes largely a speculation. Orders taken cannot be filled at agreed-on prices and contracts are cancelled. As German prices have approached world prices, new orders have declined. German industry is less and less able effectively to compete in foreign markets with nations whose financial, economic, and political conditions are on a surer, sounder foundation. For a time there was apparent industrial revival in Germany, and Germany's export trade for several months rapidly increased, as was to be expected with the coming of peace. But her trade has not reached anywhere near prewar proportions, and conditions for production are stuch in Germany that it is difficult to see how Germany can very soon be a menacing factor in world trade.

If American exporters were able to meet German competition in pre-war trade-as they were in most lines-there would seem to be small grounds for fear at the present time. Germany has emerged from the war and its aftermath a defeated nation, shorn of all her colonies and much of her productive territory at home, saddled with colossal reparation debts, deprived of her merchant marine, struggling with internal economic, social, and political problems of the gravest character. That the United States with its vast resources, its strengthened industries, its impregnable financial stability, its superb industrial organization both for producing and for selling, should look forward with greater apprehension as to her ability to compete with Germany in world markets than she did before the war is incomprehensible.

The writer of this article has not at hand detailed information as to the present competitive power of Germany in the mantufacture and sale of chemicals as compared with her power in pre-war years. The chemical industry has long been one in which Germany has had recognized advantages. The manifacture of dyes and coal-tar chemicals, particularly, had been brought to a high state of development, and Germany had, as is commonly known, almost a monopoly of world trade in many chemical products. There had thus developed in Germany a highly trained, expert force, an industrial organization and equipment of great magnitude, and a foreign market that reached every part of the world. "That in this industry German compe- 